\title{
FUNCTIONAL ENDOSCOPIC SINUS SURGERY: COMPARISON OF EFFECTIVENESS AND SAFETY IN CHILDREN AND ADULTS
}

\author{
By \\ Omar A. El-Banhawy, MD, Adel- Tharwat, MD, Amr Sobeih, \\ MD, Ahmad Abdel-Halim, MD and Ayman Aboulenean, M.D.
}

\author{
From \\ Department of ENT, Faculty of Medicine, \\ El-Menoufyia University, El Menoufyia, Egypt
}

\begin{abstract}
Background

Functional endoscopic sinus surgery (FESS) has become the primary surgical modality for treatment of chronic sinusitis. Recent studies have addressed the usefulness of endoscopic sinus surgery in pediatric patients.
\end{abstract}

Study Design : This is a retrospective randomized study and was conducted between January 1995 and January 2002 at El Menoufyia University hospital.

Objective : to evaluate the outcomes of pediatric endoscopic sinus surgery (PESS) and assess its effectiveness and safety in comparison to adult's functional endoscopic sinus surgery (FESS).
Materials and Methods : One hundred and twenty patients with primary chronic sinusitis were diagnosed and subsequently underwent endoscopic sinus surgery and they were available for follow-up ranged from 12 months to 3 years, with a mean of 2 years. Patients were classified according to the age into 2 groups: pediatric (group A) and adult (group B). The patient's symptoms on presentation were studied and analyzed. Complications occurred during performing endoscopic sinus surgery and after were documented. Postoperative symptoms were evaluated and reassessed in the follow-up period.

Results : In group A: There were no major intraoperative complications, but three patients $(5 \%)$ experienced minor operative complications as temMANSOURA MEDICAL JOURNAL 
porary diplopia (one patient) and orbital fat extrusion resulted in temporary postoperative ipsilateral facial (two patients). In group B: Intraoperative complications occurred in six patients $(10 \%)$. There was one major, cerebrospinal fluid (CSF), and five minors (temporary postoperative temporary diplopia, epiphora due to nasolacrimal duct injury which needed dacrocystorhinostomy 6 months postoperatively with successful outcome and temporary ipsilateral facial swelling in 3 patient). The difference in complication rates between PESS \& FESS was statistically significance $(p=0.026)$. Postoperative synechiae was nearly the same in both groups

Conclusion : pediatric functional endoscopic sinus surgery is the new standard for treatment of chronic sinusitis. Its operative and postoperative morbidity were less than FESS in adult.

Key words : chronic sinusitis, functional endoscopic sinus surgery.

\section{INTRODUCTION}

Functional endoscopic sinus surgery (FESS) has become a popular procedure for the treatment of adults with chronic sinusitis [1-2-3]. Generally speaking, FESS is considered to be a relatively safe and effective procedure for treating chronic sinusitis with or without nasal polyps in adults [4-5].

Chronic sinusitis is commonly seen in children and its impact has become more apparent as the awareness of the disease has increased. Its effect in the pediatric patient has expanded dramatically. Generally most patients will be cured by medical treatment and surgery is indicated when medical treatment fails [6-7]. Functional endoscopic sinus surgery in pediatric patients became the primary surgical modality for treatment of this illness in children who have not responded to optimal medical management [8-9].

Duplechain et al. [10] found that the number of missed school days was significantly reduced in $88 \%$ of the children who had undergone endoscopic sinus surgery. They found endoscopic surgery to be safe, well tolerated, and effective in the pediatric population. In a retrospective study Parsons and Phillips [8] found significant improvement in all symptoms after endoscopic sinus surgery.

Vol. 33, No. 3 \& 4 July. \& Oct, 2002 


\section{AIM OF THE WORK}

The aim of this work was to evaluate the outcome of pediatric functional endoscopic sinus surgery (PESS) and assess its effectiveness and safety in comparison to adult's functional endoscopic sinus surgery.

\section{PATIENTS AND METHODS}

This is a retrospective study was conducted between January 1995 and January 2002. The study included one hundred and twenty patients with primary chronic sinusitis who were diagnosed and subsequently underwent endoscopic sinus surgery and they were available for follow-up. Patients were managed at ENT out departments of El-Menoufyia University Hospital, Shebin El-Kom, ElMenoufyia; and El-Hikma Hospital in El-Mansoura, Dakahlia, Egypt.

Patients were classified according to the age into 2 groups: $\mathrm{A}$ and $\mathrm{B}$. $\mathrm{Pa}$ tients 16 years of age or younger were included in group (A). Above that were included in group (B).

All patients had to meet the following criteria: (1) clinical manifestation of chronic sinusitis, (2) computed tomography-proven chronic sinusitis, (3) failure of medical treatment based on the results of bacterial cultures, (4) no obstructive adenoid hyperplasia (5) no history of allergy and (6) no cystic fibrosis or immunodeficiencies.

Preoperative questionnaires asked patients to grade the severity of their symptoms (nasal obstruction, nasal discharge, nasal bleeding, recurrent infection, headache, loss of smell, facial pain, facial pressure, and posterior nasal drip) were obtained. Symptoms on presentation were studied and each symptom was graded from 0 to 3 (0 denoted none, 1 mild, 2 moderate and 3 , severe problems) (Table I).

Functional endoscopic sinus surgery procedures were done under general anesthesia in all patients. Adult functional endoscopic sinus surgery was performed using Messerklinger technique as prescribed by Stammberger [11].

Pediatric functional endoscopic sinus surgery was performed according to the way prescribed by Gross et al., 1989. The surgical pediatric operative instruments were used especially the $2.7 \mathrm{~mm}$ telescopes $(4.0 \mathrm{~mm}$ were used in some cases). Epinephrine $1: 100,000$ soaked cottonoid was

MANSOURA MEDICAL JOURNAL 
used as a surface decongestion. Xylocain with epinephrine was injected into the greater palatine foramen and root of the middle turbinate. Removal of the lower portion of the uncinate process followed by the creation of a middle meatus antrostomy using the natural ostium of the maxillary sinus and then inspection of the interior mucosa of the bulla ethmoidalis were performed. The uncinate process was taken down from lateral to medial using a back biter. A ball tipped seeker was used first to place within the infundibulum to minimally displace the uncinate anterior medially which will assist in getting the back biter in place.

With the $2.7 \mathrm{~mm} 0$ degree scope the bulla was identified and its lower medial portion is removed creating a functional opening that includes its natural ostia. If there was continued mucosal abnormalities more comprehensive surgery was preformed on the anterior and posterior ethmoid cells. If the sphenoid sinus needed to be entered, the identification of the natural ostium of the sphenoid sinus on the medial side of the superior turbinate was essential. Enlargement of the natural ostia was done using a curette taking down the lateral 'ridge' Vol. 33, No. 3 \& 4 July. \& Oct, 2002 in a posterior to anterior direction. Using careful dissection the diseased mucosa was cleansed of. Concurrent septoplasty and turbinate manipulations were done if needed.

Intranasal ribbon gauze packs with gentamycin ointment were inserted at the end of the surgery. They were re-moved after 2 days of sur-gery. Patients were instructed to use topical alkaline nasal wash frequently to minimize crusting and they were reviewed in outpatient twice weekly in the first 2 weeks, monthly, 3 months, and every 6 months after surgery during the follow-up period. Postoperative questionnaires asked patients to grade the improvement of their symptoms were taken. The follow-up period ranged from 12 months to 3 years. The questionnaires were completed at the end of follow up.

\section{RESULTS}

In group A, 60 patients, the children's age ranged from 6 to 16 years. The mean age was 10. 9 years. In group B, 60 patients, the adult age ranged from 17 to 66 years with a mean age of 43.4 years. The most common complaints in both groups were nasal obstruction, headaches, facial pressure, nasal discharge, re- 
current nasal infection, postnasal drip, loss of smell, facial pain and nasal bleeding. Table 1 demonstrates the incidence of preoperative complains in each group.

The indications for PESS in group A were chronic sinusitis without polyps in 39 operations, nasal polyps in 19 operations, and antrochoanal polyps in 2 operations. Of the operations, 51 were bilateral, and the other 9 were unilateral. The indications for FESS in group $B$ were chronic sinusitis without polyps in 30 operations, nasal polyps in 29 operations, and antrochoanal polyps in 1 operation. Bilateral operations were performed in 42 and unilateral operations in 18 cases.

There were no major operative complications in group A but 3 patients experienced minor operative complications. Temporary diplopia due to orbital penetration occurred in 1 case that had nasal polyps. It was resolved spontaneously without surgical intervention in 2 weeks. Orbital fat was extruded in 2 cases (one patient had chronic sinusitis without polyps and the other one had nasal polyps). This was resulted in temporary ipsilateral facial swelling which resolved in a weak with antiinflammatory drugs.

Intaroperative complications in group B occurred in 6 patients (10\%), one major, cerebrospinal fluid (CSF) rhinorrhea and 5 minors. CSF rhinorrhea was occurred in a 34-year-oldmale who had injury to fovea ethmoidalis, duramater and subarachenoid membrane during performing FESS for chronic ethmoidal sinusitis with polyposis. Subcranial transnasal endoscope repair of CSF fistula was done in the same sit according to the way prescribed by Wigand, 1981. The repair was healed successfully with no evidence of leak during the follow up period. Temporary diplopia was occurred in one case due to orbital penetration which was resolved spontaneously without surgical intervention.Epiphora due to nasolacrimal duct injury after FESS occurred in one case (ethmoidal sinusitis without polyposis). It was treated surgically 6 months after initial surgery by endoscopic dacrocystorhinosomy with successful outcome. Injury to Lamina Papyreccea with periorbital fat prolapsed was reported in 3 cases and resulted with temporary ipsilateral facial swelling which resolved in a weak with anti-inflammatory drugs.

MANSOURA MEDICAL JOURNAL 
The difference in complication rates between PESS and FESS was statistically significant $(p=.026)$. The operative complications for each indication are shown in Table (2).

Postoperative simple synechiae (either between middle turbinate and septum or between middle turbinate and the lateral nasal wall) were the most common problem encountered in 14 patients $(23.3 \%)$ who had PESS and 13 patients $(21.6 \%)$ who had FESS. These were easily divided under local anaethesia without need for splinting. Postoperative symptoms at the end of the follow-up period were assessed. Eighty percent of the children showed improvement based on the observations of their parents in group

A. In group B, $75 \%$ of cases had a favorable opinion of the procedure and would recommend it to others with similar problems. Improvement was judged primarily by reduced symptoms, reduced need for antibiotics, and the need for fewer doctor visits during the follow-up period. It was noticed that the degree of perceived improvement increased with the severity of each symptom. The most significant improvement $(88 \%)$ was noticed by patients with nasal obstruction. The least improvement occurred in patients with hyposmia (40\%) (Table 3).

Table (1) symptoms graded by severity in pediatric and adult groups (A\&B):

\begin{tabular}{|c|c|c|c|c|c|c|c|c|c|c|}
\hline \multirow[t]{2}{*}{$\begin{array}{l}\text { Preoperative } \\
\text { symptoms }\end{array}$} & \multicolumn{2}{|c|}{$\begin{array}{c}\text { No } \\
\text { symptoms } \\
0\end{array}$} & \multicolumn{2}{|c|}{$\begin{array}{c}\text { Mild symptoms } \\
1\end{array}$} & \multicolumn{2}{|c|}{$\begin{array}{c}\text { Moderate } \\
\text { symptoms } \\
2 \\
\end{array}$} & \multicolumn{2}{|c|}{$\begin{array}{c}\text { Sever } \\
\text { symptoms } \\
3\end{array}$} & \multicolumn{2}{|c|}{$\begin{array}{c}\text { Total } \\
\text { Symptomatic } \\
1+2+3\end{array}$} \\
\hline & $\begin{array}{c}\text { Group } \\
\text { A }\end{array}$ & $\begin{array}{c}\text { Group } \\
\text { B }\end{array}$ & $\begin{array}{c}\text { Group } \\
\text { A }\end{array}$ & $\begin{array}{c}\text { Group } \\
\text { B }\end{array}$ & $\begin{array}{c}\text { Group } \\
\text { A }\end{array}$ & $\begin{array}{c}\text { Group } \\
\text { B }\end{array}$ & $\begin{array}{c}\text { Group } \\
\mathbf{A} \\
\end{array}$ & $\begin{array}{c}\text { Group } \\
\text { B }\end{array}$ & $\begin{array}{c}\text { Group } \\
\text { A }\end{array}$ & $\begin{array}{c}\text { Group } \\
\text { B }\end{array}$ \\
\hline $\begin{array}{l}\text { Nasal } \\
\text { obstruction }\end{array}$ & 4 & 3 & 5 & 10 & 23 & 27 & 28 & 25 & $\begin{array}{c}56 \\
93.3 \% \\
\end{array}$ & $\begin{array}{c}57 \\
95 \% \\
\end{array}$ \\
\hline $\begin{array}{l}\begin{array}{l}\text { Nasal } \\
\text { discharge }\end{array} \\
\end{array}$ & 10 & 9 & 3 & 4 & 22 & 22 & 15 & 25 & $\begin{array}{c}50 \\
83.3 \% \\
\end{array}$ & $\begin{array}{c}51 \\
85 \% \\
\end{array}$ \\
\hline $\begin{array}{l}\text { Nasal } \\
\text { bleeding }\end{array}$ & 40 & 42 & 6 & 6 & 12 & 11 & 2 & 1 & $\begin{array}{c}20 \\
33.3 \% \\
\end{array}$ & $\begin{array}{c}18 \\
30 \% \\
\end{array}$ \\
\hline $\begin{array}{l}\text { Recurrent } \\
\text { infection }\end{array}$ & 10 & 16 & 9 & 8 & 21 & 19 & 20 & 19 & $\begin{array}{c}49 \\
83.3 \% \\
\end{array}$ & $\begin{array}{c}54 \\
76 \% \\
\end{array}$ \\
\hline Headache. & 9 & 5 & 12 & 14 & 21 & 22 & 18 & 19 & $85 \%$ & $\begin{array}{c}55 \\
91.6 \% \\
\end{array}$ \\
\hline $\begin{array}{l}\begin{array}{l}\text { Loss } \\
\text { smell }\end{array} \\
\end{array}$ & 20 & 15 & 9 & 9 & 15 & 16 & 15 & 20 & $\begin{array}{c}40 \\
66.6\end{array}$ & $\begin{array}{c}45 \\
75 \% \\
\end{array}$ \\
\hline Facial pain & 30 & 26 & 9 & 10 & 16 & 18 & 5 & 6 & $\begin{array}{c}30 \\
50 \% \\
\end{array}$ & $\begin{array}{c}34 \\
56.6 \% \\
\end{array}$ \\
\hline $\begin{array}{l}\text { Facial } \\
\text { pressure }\end{array}$ & 20 & 14 & 7 & 9 & 16 & 18 & 17 & 19 & $\begin{array}{c}40 \\
66 \% \\
\end{array}$ & $\begin{array}{c}46 \\
76.6 \% \\
\end{array}$ \\
\hline $\begin{array}{l}\text { Posterior } \\
\text { nasal drip }\end{array}$ & 24 & 18 & 6 & 8 & 13 & 15 & 17 & 19 & $\begin{array}{c}36 \\
60 \% \\
\end{array}$ & $\begin{array}{c}42 \\
70 \% \\
\end{array}$ \\
\hline
\end{tabular}

The last column indicates the percentage affected before FESS.

Vol. 33, No. 3 \& 4 July. \& Oct, 2002 

Table (2) Comparison of complications of endoscopic sinus surgery in pediatric and
adult groups $(A \& B)$ :

\begin{tabular}{|l|c|c|}
\hline Complication & Group A & Group B \\
\hline Synechiae & $14(23.3 \%)$ & $13(21.6 \%)$ \\
\hline Facial swelling & $3(5 \%)$ & $4(6.6 \%)$ \\
\hline Temprary diplopia & $1(1.66 \%)$ & $1(1.66 \%)$ \\
\hline Orbital fat extrusion & $2(3.33 \%)$ & $3(5 \%) \mathrm{N}$ \\
\hline Nasolacrymal duct injury & 0 & 1 \\
\hline CSF rhinorrhea & 0 & $1(1.6 \%)$ \\
\hline
\end{tabular}
Table (3) Postoperative symptoms during the follow-up in pediatric and adult groups
(A\&B):

\begin{tabular}{|c|c|c|c|c|c|c|c|c|c|c|c|c|}
\hline & \multicolumn{6}{|c|}{$\mathrm{N}=$ failure } & \multicolumn{6}{|c|}{$\mathrm{N}=$ success } \\
\hline & \multicolumn{2}{|c|}{$\begin{array}{l}\text { Much worse } \\
-2\end{array}$} & \multicolumn{2}{|l|}{$\begin{array}{l}\text { Worse } \\
-1\end{array}$} & \multicolumn{2}{|c|}{$\begin{array}{l}\text { No change } \\
0\end{array}$} & \multicolumn{2}{|l|}{$\begin{array}{l}\text { Better } \\
1\end{array}$} & \multicolumn{2}{|c|}{$\begin{array}{l}\text { Much better } \\
2\end{array}$} & \multicolumn{2}{|c|}{$\begin{array}{l}\text { Success }=\% \\
1+2 ; 60\end{array}$} \\
\hline & $\begin{array}{l}\text { Group } \\
\text { A }\end{array}$ & $\begin{array}{l}\text { Group } \\
\text { B }\end{array}$ & $\begin{array}{l}\text { Group } \\
\text { A }\end{array}$ & $\begin{array}{l}\text { Group } \\
\text { B }\end{array}$ & $\begin{array}{l}\text { Group } \\
\text { A }\end{array}$ & $\begin{array}{l}\text { Group } \\
\text { B }\end{array}$ & $\begin{array}{l}\text { Group } \\
\text { A }\end{array}$ & $\begin{array}{l}\text { Group } \\
\text { B }\end{array}$ & $\begin{array}{l}\text { Group } \\
\text { A }\end{array}$ & $\begin{array}{l}\text { Group } \\
\text { B }\end{array}$ & $\begin{array}{l}\text { Group } \\
\text { A }\end{array}$ & $\begin{array}{l}\text { Group } \\
\text { B }\end{array}$ \\
\hline $\begin{array}{l}\text { Nasal } \\
\text { obstruction }\end{array}$ & 0 & 0 & 1 & 0 & 6 & 8 & 15 & 15 & 38 & 37 & $\begin{array}{l}53 / 60 \\
88.3 \%\end{array}$ & $\begin{array}{l}52 / 60 \\
87 \%\end{array}$ \\
\hline $\begin{array}{l}\text { Nasal } \\
\text { discharge }\end{array}$ & 0 & 0 & 0 & 0 & 8 & 7 & 12 & 10 & 40 & 43 & $\begin{array}{l}52 / 60 \\
87 \%\end{array}$ & $\begin{array}{l}53 / 60 \\
88.3 \%\end{array}$ \\
\hline $\begin{array}{l}\text { Nasal } \\
\text { bleeding }\end{array}$ & 0 & 0 & 0 & 1 & 16 & 13 & 20 & 27 & 24 & 19 & $\begin{array}{l}44 / 60 \\
73.3 \%\end{array}$ & $\begin{array}{l}46 / 60 \\
76.6 \%\end{array}$ \\
\hline $\begin{array}{l}\text { Recurrent } \\
\text { infection }\end{array}$ & 0 & 1 & 2 & 1 & 5 & 8 & 20 & 23 & 23 & 27 & $\begin{array}{l}53 / 60 \\
88.3 \%\end{array}$ & $\begin{array}{l}5060 \\
83.3 \%\end{array}$ \\
\hline Headache. & 0 & 0 & 0 & 2 & 6 & 8 & 27 & 25 & 27 & 25 & $\begin{array}{l}54 / 60 \\
90 \%\end{array}$ & $\begin{array}{l}50 / 60 \\
83.3 \% 1\end{array}$ \\
\hline $\begin{array}{l}\text { Loss of } \\
\text { smell }\end{array}$ & 0 & 0 & 1 & 2 & 35 & 34 & 22 & 21 & 12 & 3 & $\begin{array}{l}24 / 60 \\
40 \%\end{array}$ & $\begin{array}{l}24 / 60 \\
40 \% \\
\end{array}$ \\
\hline Facial pain & 0 & 0 & 1 & 1 & 10 & 9 & 21 & 22 & 28. & 28 & $\begin{array}{l}49 / 60 \\
81.6 \% \\
\end{array}$ & $\begin{array}{l}50 / 60 \\
83.3 \%\end{array}$ \\
\hline $\begin{array}{l}\text { Facial } \\
\text { pressure } \\
\text { Posterior }\end{array}$ & 0 & 1 & 2 & 2 & 18 & 18 & 15 & 15 & 25 & 24 & $\begin{array}{l}40 / 60 \\
66.6 \% \\
\end{array}$ & $\begin{array}{l}39 / 60 \\
65 \% \\
\end{array}$ \\
\hline $\begin{array}{l}\text { Posterior } \\
\text { nasal drip }\end{array}$ & 1 & 1 & .2 & 1 & 25 & 28 & 4 & 4 & 28 & 26 & $\begin{array}{l}32.60 \\
53.3 \%\end{array}$ & $\begin{array}{l}30 / 60 \\
50 \%\end{array}$ \\
\hline
\end{tabular}




\section{DISCUSSION}

Functional endoscopic sinus surgery has been accepted as a minimally invasive technique for the treatment of nasal polyposis, and chronic and acute recurrent sinusitis resistant to medical therapy [4]. Recent studies have addressed the usefulness of FESS in both adult and pediatric patients [7-12]. Moreover the results of PESS also provide evidence of its efficacy for the treatment of chronic sinusitis in children [13].

History of illness remains the most important factor in predicting the patients who may benefit most from PESS and FESS. In this study, patients with severe nasal obstruction and headache not otherwise explained except for the associated chronic sinus disease benefited most from PESS and FESS, while those with postnasal drip and loss of smell experienced the least amount of relief (Table 3). This result agreed with that of [14- 15-16] for pediatric chronic sinusitis who underwent PESS and with that of $[17-18-19-9]$,for adult chronic sinusitis.

Generally, complications of endoscopic sinus surgery are divided into nasal, orbital and intracranial compli- cations. Nasal complications include bleeding, infection, synechiae and anosmia. Orbital complications include epiphora, ocular muscle damage (especially the medial rectus muscle), orbital hematoma, optic nerve injury, globe rupture and loss of vision. The intracranial complications include damage to the internal carotid artery (as it lies at the lateral wall of the sphenoid sinus), cerebrospinal fluid leakage, intracranial hematoma and brain injury [20-21-22]. These complications are also classified according to their severity into minor and major complications.

In the current work the most common complications encountered involved intranasal synechiae in $14 \mathrm{pa}$ tients (23.3\%) who had PESS and 13 patients $(21.6 \%)$ who had FESS. Close outpatient postoperative care with meticulous cleaning of the nasal cavity under endoscopic guidance can easily prevent most of these adhesions [1]. Facial swelling occurred in 3 patients $(5 \%)$ who had PESS and 4 patients $(6.6 \%)$ who had FESS. These were due to injury to Lamina Papyreccea and exposure of periorbital fat during performing ethmoidiectomy. The facial swelling resolved spontaneously in 2 weeks time. The result 
of the current work is in agreement with that reported by Stankiewicz [1415-16], Rosenfeld [15], Ramadan [16], during PESS and with Lusk [17], 1992, Lansa and Kennedy [18], Hossmann [18], during FESS [23].

The paranasal sinuses are intimately related to the orbit and consequently sinus disease or surgery may cause severe orbital complications [24]. There was a case with lacrimal drainage system injury after functional endoscopic sinus surgery in group B. Unlu et al. [25], analyzed 31 patients after FESS by dacryocystography imaging and they reported bony dehiscence in $53.2 \%$ of the operated sides but also in $20 \%$ of the nonoperated sides. No passage of the contrast material into the inferior meatus was observed in $14.9 \%$ of the operated sides. They concluded that lacrimal drainage system injury might occur in various extents during functional endoscopic sinus surgery and performing the middle meatal antrostomy in posteroinferior direction, and uncinectomy with backbiting forceps or a shaver might help in reducing the lacrimal injury.

CSF rhinorrhea is a wellrecognized complication of ESS and occurs in $0.5 \%$ of cases [22]. We encountered one major complication of CSF leak during performing FESS in and adult patient with chronic sinusitis. The location of CSF leak was at the lateral cribriform plate lamella at the level of the anterior ethmoid artery where the bone can be as little as thin as $0.1-\mathrm{mm}$ in thickness. CSF fistula was repaired in the same setting with successful out come. Myers and Sataloff [25], pointed out to the commonest errors resulting in CSF leak during endoscopic sinus surgery, which were working from lateral to medial and anterior to posterior at the anterior skull base. The skull base slopes from anterior-superior to posterior-inferior and can be easily penetrated if working toward it as opposed to away from it (posterior to anterior) [26]. The sloping nature of the skull base allows for removal of bony lamella by pulling down away from the skull base rather than pushing forward into it. The Messerklinger technique is therefore important to master in the cadaver lab before attempting endoscopic sinus surgery at the skull base [11].

PESS appears to offer a safe and effective technique to control sinus disease in children who do not respond to aggressive medical manage-

MANSOURA MEDICAL JOURNAL 
ment. In skilled hands, this technique is associated with few complications. In this work PESS procedures we performed were similar to those of FESS. However, the extent of surgery was based on the findings of computed tomography. Since the frontal and sphenoid sinuses are less developed in children than in adults, frontal and sphenoid sinuses were less frequently opened in PESS than in FESS, so complications were to some extent less.

A meta-analysis of the literatures was performed by Gross et al. [6] and Hebert and Bent [13], focusing on the number of patients per study, length of follow-up, prospective versus retrospective, and the separation or exclusion of patients with significant underlying systemic diseases (cystic fibrosis and immunodeficiencies) provided evidence that PESS is an effective procedure for the treatment of chronic sinusitis in children, but longterm results yielding firm conclusions have yet to be reported.

In conclusion pediatric functional endoscopic sinus surgery is the new standard for treatment of chronic sinusitis. Its operative and postoperative morbidity were less than FESS in Vol. 33, No. 3 \& 4 July. \& Oct, 2002 adult.

\section{REFERENCES}

1- Kennedy DW and others (1985) :

Functional endoscopic sinus surgery: theory and diagnostic evaluation, Arch Otolaryngol Head Neck Surg 111:576.

2- Senior BA, Kennedy DW, Tanabodee J, Kroger $\mathbf{H}$, Hassab M, Lanza D. (1998) : Longterm results of functional endoscopic sinus surgery. Laryngoscope; 108:151-7.

3- Bothwell MR, Piccirillo JF, Lusk RP, Ridenour BD. (2002) : Long-term outcome of facial growth after functional endoscopic sinus surgery. Otolaryngol Head Neck Surg Jun; 126(6):628-34.

4- Levine HL. (1990) : Functional endoscopic sinus surgery: Evaluation, surgery, and follow-up of 250 patients. Laryngoscope; 100:79-84.

\section{5- Damm M, Quante G, Jungehuels- ing M, Stennert E. (2002) : Impact of functional endo-}


scopic sinus surgery on symptoms and quality of life in chronic rhinosinusitis. Laryngoscope Feb; 112(2):310-5.

6- Gross CW, Gurucharii MJ, Lazar RH, Long TE. (1989) : Functional endonasal sinus surgery (FESS) in the pediatric age group. Laryngoscope; 99:272-5.

\section{7- Haltom JR, Cannon CR (1998) :} Functional endoscopic sinus surgery: results in the young child. Miss State Med Assoc Dec; 39(12):445-9.

\section{8- Parsons DS, Phillips SE (1993) :} Functional endoscopic surgery in children: a retrospective analysis of results, Laryngoscope 103:89.

9- Jiang RS, Hsu CY. (2000) : Functional endoscopic sinus surgery in children and adults. Ann Otol Rhinol Laryngol Dec; 109(12 Pt 1):1113-6.

10- Duplechain JK, White JA, and Miller RH (1991) : Pediatric sinusitis: the role of endo- scopic sinus surgery in cystic fibrosis and other forms of sinonasal disease, Arch Otolaryngol Head Neck Surg 117:422.

11- Stammberger, H. (1990) : Functional endoscopic sinus surgery. The Messeridinger's technique. BC Decker, Philadelphia.

12- Jakobsen J, Svendstrup F. (2000) : Functional endoscopic sinus surgery in chronic sinusitis--a series of 237 consecutively operated patients. Acta Otolaryngol Suppl; 543:158-61.

13- Hebert RL, Bent JP. (1998) : Meta-analysis of outcomes of pediatric functional endoscopic sinus surgery. Laryngoscope; 108:796-9.

14- Stankiewicz JA (1995) : Pediatric endoscopic nasal and sinus surgery. Otolaryngol Head Neck Surg Sep; 113(3):20410.

15- Rosenfeld RM (1995) : Pilot study of outcomes in pediatMANSOURA MEDICAL JOURNAL 
ric rhinosinusitis. Arch Otol-

aryngol Head Neck Surg Jul; 121(7):729-36.

16- Ramadan $\mathrm{HH}$ (1999) : Adenoidectomy vs endoscopic sinus surgery for the treatment of pediatric sinusitis. Arch Otolaryngol Head Neck Surg Nov; 125(11):1208-11.

17- -Lusk RP. (1992) : Functional approach to sinus disease. Allergy Clinic Immunol; 90: 496-505.

18- Lansa DC, Kennedy DW. (1992) : Current concepts in the surgical management of chronic and recurrent acute sinusitis. 3 Allergy Clin Immunol; 90:505.

19- Hossmann W. (1993) : Indications, technique and results of endonasal endoscopic ethmoidectomy. Acts CtoRhino-lasryngologica; 47:73-83.

20- Maniglia AJ. (1989) : Fatal and major complications secondary to nasal and sinus sur- gery. Laryngoscope; 99; 276-83.

21- Vleming M, Middelweed RI, Vries ND. (1992) : Complications of endoscopic sinus surgery. Arch Otolaryngol, Head Neck Surg ;11g:61723.

22- Kinsella JB and others (1995) : Complications of endoscopic sinus surgery in a residency training program, Laryngoscope 105: 1029.

23- Tzifa KT, Skinner DW. (2001) : Peri-orbital surgical emphysema following functional endoscopic sinus surgery, during extubation. J Laryngol Otol Nov; 115 (11):916-7 .

24- Rene C, Rose GE, Lenthall R, Moseley I. (2001) : Major orbital complications of endoscopic sinus surgery. $\mathrm{Br}$ $\mathrm{J}$ Ophthalmol. Nov; 85 (11):1394.

25- Unlu HH, Goktan C, Aslan A, Tarhan S. (2001) : Injury

Vol. 33, No. 3 \& 4 July. \& Oct, 2002 
Omar A. El-Banhawy et al ....

to the lacrimal apparatus after endoscopic sinus surgery : surgical implications from active transport dacryocystography. Otolaryngol Head Neck Surg Mar; 124(3):308-12.

26- Myers DL, Sataloff RT (1984)
: Spinal fluid leakage after skull base surgical procedures. Otolaryngol Clin North Am., 17:601-611.

27- Charles DA, Snell D (1979) : Cerebrospinal fluid rhinorrhea. Laryngoscope, 89 : 822-826. 
